\title{
Feasibility Test of Reproductive Health Gymnastics Video Media for Socialization to Adolescent Girls
}

\author{
Widyaning Dara Utami, Rr. Sri Endang Pujiastuti, Mateus Sakundarno Adi \\ Poltekkes Kemenkes Semarang, Indonesia \\ *widya.dara22@gmail.com
}

\begin{abstract}
Reproductive health gymnstics is one type of physical activity which, if carried out regularly, can increase oxygen consumption related to hemoglobin as a carrier protein in erythrocytes to reach cells. The development of socialization media in the form of reproductive health gymnstics videos has been carried out, but the feasibility of giving it to respondents is not yet known. The method used is part of research and development in an effort to develop reproductive health gymnstics videos for the socialization of reproductive health gymnstics. The research and development stages used in this study are limited to the feasibility test of video media. The sample of experts in this study amounted to 3 experts and the sample of adolescents amounted to 30 adolescent girls.

The test used to analyze the feasibility of a reproductive health gymnstics video media based on 7 aspects of feasibility, namely subject matter, auxiliary information, affective, considerations, interface, navigation, pedagogy, robustness by experts, namely the intraclass correlation coefficient test, the results obtained $\rho$ value $0.017<0.05$. which means that reproductive health gymnstics videos are relevant and appropriate as a medium for socialization of reproductive health gymnstics to adolescent girls. The respondents' assessment of the reproductive health gymnstics video media, the majority, considered that this media was very suitable to be used as a media for socializing reproductive health gymnstics.
\end{abstract}

This study shows that reproductive health gymnstics videos are relevant and feasible as a medium for socializing reproductive health gymnstics to adolescent girls

Keywords : Feasibility, Video Media, Reproductive Health Gymnastics 


\section{STRADA Jurnal Ilmiah Kesehatan}

DOI: $10.30994 /$ sjik.v9i2.448

ISSN: 2252-3847 (print); 2614-350X (online)

Vol.9 No.2 November 2020 Page.1196-1206

\section{BACKGROUND}

Gymnastics is a type of sport or physical activity that can be done to get a fit and healthy body. (Ramandhasari \& Legowo, 2014) Doing physical activity at least once a week can reduce the intensity of discomfort in the body because there are endorphins. This hormone acts as a natural sedative, causing a feeling of comfort. Beta-endorphins trigger further processes, namely strengthening immunity and increasing memory and stamina, and even have analgesic (painkilling) effects. (Tahun, 2016)

Physical activity carried out routinely and repeatedly can increase oxygen consumption related to hemoglobin as a carrier protein that is in erythrocytes to reach cells. Hemoglobin in the human body has an important function, namely transporting oxygen from the respiratory organs (lungs) to the rest of the body, so that activities carried out routinely and in a planned manner have the aim of increasing the degree of health.(Fitria, Pujiastuti, \& Mulyantoro, 2018)

Health problems that are often experienced by adolescent girls that interfere with their health, namely anemia. WHO data shows that $40 \%-88 \%$ of anemia sufferers occur in adolescent girls.(World Health Organization, 2011) Based on the 2018 Riskesdas data the incidence of anemia has increased compared to the 2013 Riskesdas data which shows that the incidence of anemia from $21.7 \%$ to $23.7 \%$ with a greater percentage of women, namely $27.2 \%$ compared to men by $20.3 \%$. Based on the characteristics of the age group, the prevalence of anemia aged 5-14 years is $26.8 \%$; and the prevalence of anemia incidence aged 15-24 years is $32 \%$.(Kementerian Kesehatan RI, 2018) The results of the study related to factors related to the incidence of anemia in female adolescents said that the average age of 13 years of age for the first time in adolescent girls was that of iron deficiency anemia was 27.5\%.(Listiana, 2016) In 2018, the prevalence of anemia in Central Java was $57.1 \%$; while in Semarang, the incidence of anemia in adolescent girls is 26\% .7 Female adolescent anemia is a problem because the prevalence is more than 20\%.(Budiharjo, Qomariah, Kesehatan, Semarang, \& Asuh, 2018) The indicator for an adolescent girl having anemia is if the hemoglobin level in the body is <12 gr / dL.(Vandermeulen \& Sholzberg, 2018)

The incidence of anemia in adolescent girls has a relationship with the incidence of dysmenorrhea.(Cholifah, 2015) Anemia occurs due to a lack of iron, which causes the transport of oxygen needed to the body's tissues to decrease. Lack of oxygenation in the lungs to the body's tissues causes an increase in carbon dioxide and prostaglandins in the body which can trigger uterine contractions.(Aziza, 2015) Types of dysmenorrhea are divided into 2, namely primary dysmenorrhea and secondary dysmenorrhea, called primary dysmenorrhea if no underlying cause is found and secondary dysmenorrhea if the cause is an uterine abnormality. Dysmenorrhea generally occurs about 2 or 3 years after the first menstruation.(Prawiroharjo, 2011) In Indonesia, the incidence of dysmenorrhea is $64.25 \%$ consisting of $54.89 \%$ primary dysmenorrhea (no uterine abnormalities) and $9.36 \%$ secondary dysmenorrhea (there are abnormalities in the uterus).(Proverawati, 2009) The incidence of dysmenorrhea in Central Java reaches 56\%. Meanwhile, in the city of Semarang, based on the results of a study conducted in 2014, 83.3\% of Semarang City adolescents had mild dysmenorrhea and $16.7 \%$ had severe dysmenorrhea.(Fatmawati, Riyanti, \& Widjanarko, 2016)

Based on the 2018 IDHS, the government's program to overcome adolescent anemia is by distributing blood-supplemented tablets to young girls, while for dysmenorrhea no special program has been implemented. The high incidence of anemia and dysmenorrhea has encouraged researchers to conduct research in an effort to overcome 


\section{STRADA Jurnal Ilmiah Kesehatan}

DOI: $10.30994 /$ sjik.v9i2.448

ISSN: 2252-3847 (print); 2614-350X (online)

Vol.9 No.2 November 2020 Page.1196-1206

this problem. . Various kinds of physical activities that have been previously studied include aerobic exercise, body stretching, yoga, zumba, Kegel exercises, menstrual pain exercises, dysmenorrhea exercises, body language exercises, reproductive health exercises, and various other exercises. For example, a study conducted by Destia in 2015 on the effectiveness of dysmenorrhea in the treatment of primary menstrual pain in adolescents showed that there were differences in dysmenorrhea between the control and intervention groups. A similar study was conducted by Ahmed in 2019 with the intervention used was zumba to reduce primary menstrual pain which showed the results that the intensity of menstrual pain decreased significantly in the intervention group. There was also research on the relationship between physical activity and iron levels in women's bodies by Scott in 2012 which explained that people with significantly less iron did less physical activity. Gymnastics is a physical activity that is in great demand by the community, especially adolescent girls.(Widayanti, Mudayanti, \& Susmini, 2017)'(Article, 2016)'(Denis \& Conway, 2018) Exercise is not expensive, easy to do, light, and does not cause harmful side effects to the body.(Ismarozi, Utami, \& Novayelinda, 2015)

Reproductive health gymnastics is a new exercise product that was first researched by Fitria. Reproductive health gymnastics was adopted from aerobic exercise and SKJ (Physical Fitness Gymnastics) in 2012.(Fitria et al., 2018) Research on reproductive health gymnastics that has been carried out by Fitria produces a product in the form of a module which in the module explains that reproductive health gymnastics can be used to improve physical fitness, increase hemoglobin levels, overcome dysmenorrhea, and various reproductive disorders.(Fitria et al., 2018)

Preliminary studies conducted by researchers at this time showed that out of 120 adolescent girls only $18(0.15 \%)$ of adolescent girls had received information related to reproductive health gymnastics. Existing data indicate that the efforts to socialize reproductive health gymnastics using products produced by previous researchers are not optimal as a medium for socialization for adolescent girls. Efforts to socialize reproductive health gymnastics need practical media that make it easier for adolescent girls to access and learn about reproductive health gymnastics both in material and at the same time. Easy access to information is expected to optimize the goals and benefits of reproductive health gymnastics, so that it can help efforts to minimize adolescent reproductive health problems.

Based on the concept of cone of experience, it is explained that the more complex the sensory aspects used in the learning process, the better individual understanding will be.(Shaluhiyah Z. \& N., 2017) Video tutorials are a method of providing information that uses audio and visual aspects to be demonstrated by the target, so that the information will be remembered more by the respondent than if the provision of information only uses audio or visual aspects.

The need for media development for the socialization of reproductive health gymnastics is supported by the information the researchers got through interviews. Researchers conducted interviews with several resource persons related to reproductive health gymnastics, the first was with practitioners in the field, who expressed the following opinion: "So far the program to overcome adolescent anemia has been carried out in schools only by distributing blood-supplemented tablets, whereas there has not been any dysmenorrhea. special handling. There are still many students who do not know about reproductive health gymnastics and its purposes and benefits, we need media that can help students in school to understand and learn about these exercises." 


\section{STRADA Jurnal Ilmiah Kesehatan}

DOI: $10.30994 /$ sjik.v9i2.448

ISSN: 2252-3847 (print); 2614-350X (online)

Vol.9 No.2 November 2020 Page.1196-1206

The second interview was with a junior high school student who expressed the following opinion: "The giving of blood supplemented tablets was done through the homeroom teacher, which was then distributed to us, but not all students were orderly taking the blood added tablets that were distributed, and when I was menstruating I often felt menstrual pain. which makes me feel uncomfortable and hard to focus while studying. So far, I never knew that there was exercise that could help with menstrual pain and anemia."

The third interview was conducted with gymnastics experts who expressed the following opinion: "Gymnastics to improve adolescent reproductive health is a good idea to develop, with a note that gymnastics that are suitable for reproductive health are exercises with light weights that do not have movements such as jumping or running with the appropriate training intensity. The characteristics of teenagers now that the majority feel lazy to move, they tend to spend time in front of gadgets, so the role of the media in developing socialization is important."

The results of interviews with various parties were then used as material for consideration to develop a media for socialization of reproductive health gymnastics in the form of videos that the researchers had made. The development of reproductive health gymnastics videos was made on the basis of reproductive health modules with a video duration of \pm 20 minutes. The video uses a count with a range of accompaniment music beats between 90 beats / minute - 130 beats / minute which is divided into 3 sessions, namely warming up, core movement, and cooling down. The video contains an explanation related to an introduction to gymnastics and an explanation of each movement that is carried out. Video on reproductive health gymnastics is currently available, but its feasibility is not yet known to be used as a media for socializing reproductive health gymnastics for adolescent girls, so researchers want to test the feasibility of reproductive health gymnastics videos as a media for socializing reproductive health gymnastics for adolescent girls.

\section{METHODS}

The method used in this research is the method of research and development (Research and Development) which in this study the research and development stage is focused on the product feasibility test stage on reproductive health gymnastics video media that has been made by researchers but has not been tested for its feasibility to be used as a media of socialization for adolescents. .

The research was conducted in July - August 2020 in Semarang City. The target population in this study were experts / experts on video gymnastics research products and adolescent girls at SMPN 21 Semarang. The study population in this study were experts / experts with a minimum education of undergraduate and grade 8 adolescent girls. The sample of experts in this study were 3 experts in the following fields :

a. Material expert: lecturer of Physical Education, Health and Recreation, Unversitas

Negeri Semarang

b. Health promotion specialist: lecturer in Nursing at Universitas Diponegoro

c. Practitioners: teacher of SMP Negeri 27 Semarang.

The sample of adolescent girls in this study was taken as many as 30 adolescents to assess the reproductive health gymnastics video media.(Saputro, 2017)

The research instrument used was the reproductive health gymnastics video media and the media eligibility questionnaire. Data analysis in this study was used to analyze the suitability of the reproductive health gymnastics video media based on 7 feasibility aspects 


\section{STRADA Jurnal Ilmiah Kesehatan}

DOI: $10.30994 /$ sjik.v9i2.448

ISSN: 2252-3847 (print); 2614-350X (online)

Vol.9 No.2 November 2020 Page.1196-1206

with a frequency distribution, the results would be categorized as very feasible if the mean value was $4-5$; feasible if the mean values are $3-3,9$; sufficient if the mean is $2-2.9$; less good if the mean value is $1-1.9$; very less good if the mean value is $0-0.9$. The next analysis is to analyze the expert validity value using the intraclass correlation coefficient to determine the feasibility of the product. The Ethical Clearance (EC) of this study has been issued by the Health Research Ethical Commission of the Poltekkes Kemenkes Semarang with number 049 / EA / KEPK / 2020 valid from 6 March 2020 - 6 March 2021.

\section{RESULT}

\section{A. Feasibility Aspects of Reproductive Health Gymnastics Video Media}

The test on the feasibility of the reproductive health gymnastics video media was conducted by 3 experts before the video was assessed by the teenagers in order to know the readiness of the video to be distributed to teenagers. The assessment is carried out at each expert institution by showing videos to the experts and the experts can provide feedback through a questionnaire that the researcher has prepared. Details of expert assessment scores can be seen in the table as follows :

Table A.1 Details of Expert Rating Scores

\begin{tabular}{|c|l|c|c|c|}
\hline No & \multicolumn{1}{|c|}{ Questions } & $\begin{array}{c}\text { Expert } \\
1 \\
\text { (Materi } \\
- \text { al) }\end{array}$ & $\begin{array}{c}\text { Expert 2 } \\
\text { (Health } \\
\text { Promotio } \\
\text { n) }\end{array}$ & $\begin{array}{c}\text { Expert } \\
3 \\
\text { (Practi- } \\
\text { tioners) }\end{array}$ \\
\hline 1 & $\begin{array}{l}\text { Conformity with basic gymnastics } \\
\text { competencies }\end{array}$ & 4 & 3 & 4 \\
\hline 2 & $\begin{array}{l}\text { The accuracy of the selection of } \\
\text { gymnastic movements }\end{array}$ & 4 & 3 & 5 \\
\hline 3 & $\begin{array}{l}\text { The suitability of gymnastics to } \\
\text { encourage the development of physical } \\
\text { aspects }\end{array}$ & 4 & 3 & 5 \\
\hline 4 & $\begin{array}{l}\text { The suitability of gymnastics to } \\
\text { encourage the development of } \\
\text { cognitive aspects }\end{array}$ & 5 & 5 & 5 \\
\hline 5 & $\begin{array}{l}\text { The suitability of gymnastics to } \\
\text { encourage the development of } \\
\text { psychomotor aspects }\end{array}$ & 5 & 5 & 5 \\
\hline 6 & $\begin{array}{l}\text { Safety and durability of exercise } \\
\text { videos to be applied to adolescent girls }\end{array}$ & 5 & 5 & 5 \\
\hline 7 & Clarity of gymnastics instructions & 5 & 3 & 4 \\
\hline 8 & Music suitability & 5 & 5 & 5 \\
\hline 9 & Compatibility of gymnastic counts & 5 & 5 & 5 \\
\hline 10 & $\begin{array}{l}\text { The suitability of the duration of } \\
\text { gymnastics }\end{array}$ & 5 & 4 \\
\hline 11 & Gymnastics video display & & & 5 \\
\hline
\end{tabular}




\section{STRADA Jurnal Ilmiah Kesehatan}

DOI: $10.30994 /$ sjik.v9i2.448

ISSN: 2252-3847 (print); 2614-350X (online)

Vol.9 No.2 November 2020 Page.1196-1206

The results of filling out the questionnaire conducted by experts can be interpreted in the form of a chart as follows:

Chart A.1 Score Based on Feasibility Aspects

\begin{tabular}{|r|r|r|r|r|r|r|}
\hline $\begin{aligned} 6 \\
5 \\
4 \\
3 \\
2 \\
1\end{aligned}$ \\
0
\end{tabular}

Table A.1 and chart A.1 describe the expert's assessment based on a questionnaire that has been adjusted to 7 aspects of feasibility. The average score for each aspect shows that the majority of the categories are very feasible and the categories are feasible for the pedagogy aspect.

\section{B. Feasibility Test for Reproductive Health Gymnastics Video Media}

1. Expert Validation

Media validation was carried out as a basis for testing the feasibility of reproductive health gymnastics videos as a medium for socializing reproductive health gymnastics with a questionnaire containing 11 questions from each expert validator. The validation results obtained from all experts obtained a score of 4.4 (good or feasible). These results can be seen in the following table:

Table B.1 Validation Results of Reproductive Health Gymnastics Videos by Experts

\begin{tabular}{cc}
\hline Expert & Average \\
\hline Material & 4,6 (Sangat layak) \\
Health promotion specialist & 3,9 (Layak) \\
Practitioners & 4,7 (Sangat layak) \\
\hline Total & 4,4 (Sangat layak) \\
\hline
\end{tabular}

Table B.2 Result of Intraclass correlation coefficient

\begin{tabular}{lllc}
\hline & \multicolumn{1}{c}{ Validitas Ahli } & \\
\hline & $\mathrm{N}$ & $\mathrm{f}(\%)$ & -value \\
\hline Relevant & 11 & 100 & 0,017 \\
\hline Irrelevant & 0 & 0 & \\
\hline
\end{tabular}

The results of the validity of the experts showed that the total average value was 4.4 and the $p$-value $=0.017$, which means that reproductive health gymnastics videos are relevant and feasible as a medium for the optimization of the socialization of reproductive health gymnastics in adolescent girls. 


\section{STRADA Jurnal Ilmiah Kesehatan}

DOI: $10.30994 /$ sjik.v9i2.448

ISSN: 2252-3847 (print); 2614-350X (online)

Vol.9 No.2 November 2020 Page.1196-1206

The reproductive health gymnastics video tutorials that have been validated by experts are revised based on the input given from each assessor. Inputs given are the props using colors that enhance enthusiasm such as green or red, the video lighting is adjusted so that it is easy to see, and an explanation of the objectives of the exercise before starting using audio.

2. Adolescent Media Feasibility Assessment

The assessment of the feasibility of the reproductive health gymnastics video media by adolescent girls was carried out using a questionnaire which first tested the validity and reliability. The results of the validity test stated that 11 questionnaires for the feasibility of reproductive health gymnastics video media were valid because $r$ count was greater than $r$ table $(r>0.381)$ with a range of $r$ count $0.382-0.947$. Reliability testing in this study used Cronbach's Alpha technique. The results of the reliability test stated that the 11 feasibility questionnaires for reproductive health gymnastics video media were reliable because Cronbach's Alpha value was more than 0.6 , namely 0.934 .

The following is a detailed table of the results of the feasibility assessment of the reproductive health gymnastics video media by adolescents using a questionnaire that has been tested for validity and reliability along with the calculated $r$ value of the questionnaire items:

Table B.3 Detailed Results of Media Feasibility Assessment by Adolescents

\begin{tabular}{|c|c|c|c|c|c|c|c|c|c|c|c|c|}
\hline \multirow{2}{*}{ No } & \multirow{2}{*}{ Question } & \multirow{2}{*}{$\begin{array}{c}\mathrm{r} \\
\text { count }\end{array}$} & \multicolumn{2}{|c|}{1} & \multicolumn{2}{|c|}{2} & \multicolumn{2}{|c|}{3} & \multicolumn{2}{|c|}{4} & \multicolumn{2}{|c|}{5} \\
\hline & & & $\mathrm{n}$ & $\%$ & $\mathrm{~N}$ & $\%$ & $\mathrm{n}$ & $\%$ & $\mathrm{n}$ & $\%$ & $\mathrm{n}$ & $\%$ \\
\hline 1 & $\begin{array}{l}\text { The clarity of the } \\
\text { reproductive health } \\
\text { gymnastics video } \\
\text { movement }\end{array}$ & 0,807 & - & - & 2 & 6,7 & 4 & 13,3 & 16 & 53,3 & 8 & 26,7 \\
\hline 2 & $\begin{array}{l}\text { Clarity of text for } \\
\text { reproductive health } \\
\text { gymnastics instructions }\end{array}$ & 0,816 & 2 & 6,7 & - & - & 4 & 13,3 & 16 & 53,3 & 8 & 26,7 \\
\hline 3 & $\begin{array}{l}\text { Reproductive health } \\
\text { gymnastics video } \\
\text { display }\end{array}$ & 0,382 & - & - & - & - & 11 & 36,7 & 11 & 36,7 & 8 & 26,7 \\
\hline 4 & $\begin{array}{l}\text { The suitability of the } \\
\text { selection of } \\
\text { accompaniment music } \\
\text { in reproductive health } \\
\text { gymnastics }\end{array}$ & 0,648 & - & - & 2 & 6,7 & 4 & 13,3 & 16 & 53,3 & 8 & 26,7 \\
\hline 5 & $\begin{array}{l}\text { The suitability of the } \\
\text { calculation of } \\
\text { reproductive health } \\
\text { gymnastics }\end{array}$ & 0,858 & - & - & 4 & 13,3 & 2 & 6,7 & 14 & 46,7 & 10 & 33,3 \\
\hline 6 & $\begin{array}{l}\text { The suitability of the } \\
\text { health gymnastics } \\
\text { movement } \\
\text { reproduction }\end{array}$ & 0,889 & - & - & 2 & 6,7 & 2 & 6,7 & 14 & 46,7 & 12 & 40,0 \\
\hline 7 & $\begin{array}{l}\text { The suitability of the } \\
\text { duration / time of the } \\
\text { implementation of } \\
\text { reproductive health } \\
\text { gymnastics }\end{array}$ & 0,542 & - & - & 4 & 13,3 & 10 & 33,3 & 14 & 46,7 & 2 & 6,7 \\
\hline 8 & $\begin{array}{l}\text { Ease and variety of } \\
\text { reproductive health }\end{array}$ & 0,858 & - & - & 4 & 13,3 & 2 & 6,7 & 12 & 40,0 & 12 & 40,0 \\
\hline
\end{tabular}




\section{STRADA Jurnal Ilmiah Kesehatan}

DOI: $10.30994 /$ sjik.v9i2.448

ISSN: 2252-3847 (print); 2614-350X (online)

Vol.9 No.2 November 2020 Page.1196-1206

\begin{tabular}{|c|c|c|c|c|c|c|c|c|c|c|c|c|}
\hline & gymnastics movements & & & & & & & & & & & \\
\hline 9 & $\begin{array}{l}\text { Reproductive health } \\
\text { gymnastics is suitable } \\
\text { for adolescent health } \\
\text { exercise }\end{array}$ & 0,947 & 2 & 6,7 & 2 & 6,7 & - & - & 4 & 13,3 & 22 & 73,3 \\
\hline 10 & $\begin{array}{l}\text { Reproductive health } \\
\text { gymnastics can provide } \\
\text { motivation and } \\
\text { happiness }\end{array}$ & 0,855 & 4 & 13,3 & - & - & 2 & 6,7 & 14 & 46,7 & 10 & 33,3 \\
\hline 11 & $\begin{array}{l}\text { Ease of accessing } \\
\text { reproductive health } \\
\text { gymnastics videos }\end{array}$ & 0,863 & 4 & 13,3 & - & - & 2 & 6,7 & 14 & 46,7 & 10 & 33,3 \\
\hline
\end{tabular}

The following is a table of the results of the feasibility assessment of the reproductive health gymnastics video media by adolescents using a questionnaire that has been tested for validity and reliability:

Table B.4 Results of Media Feasibility Assessment by Adolescents

\begin{tabular}{ccc}
\hline Feasibility Category & Amount $(\mathrm{n})$ & Percentage $(\%)$ \\
\hline Very feasible & 24 & 80 \\
Feasible & 2 & 6,7 \\
Decent enough & 2 & 6,7 \\
Less feasible & 2 & 6,6 \\
Very less feasible & 0 & 0 \\
\hline Total & 30 & 100 \\
\hline
\end{tabular}

Table B.4 shows that the majority of adolescents consider that the reproductive health gymnastics video media is very suitable to be used as a media for socializing reproductive health gymnastics.

\section{DISCUSSION}

\section{A. Aspek Kelayakan Media Video Senam Kesehatan Reproduksi}

The assessment of the feasibility of the reproductive health gymnastics video media showed that the majority of the results were in the very appropriate category to be used as socialization media for adolescents, except for the pedagogy aspect which was in the lower category which was feasible. Health promotion experts argue that education about reproductive health gymnastics that is included in the video will be better if it is only placed at the beginning of the video with added audio / dubbing so that teenagers can understand without having to look at the text and not destroy the youth's focus on the exercise movement. Unlike the exercise manual text for better auxiliary information aspects without dubbing, it is necessary to pay attention to the interface aspect in the form of the color suitability of the instructional text and the video background so that the text can be read comfortably and the selection of simple video transitions so as not to interfere with the exercise movements. Instructions for gymnastics danpa dubbing aim so as not to interfere with gymnastics navigation, namely the count of gymnastics. The gymnastic count follows the rhythm of the selected gym beat and coordinated harmoniously between music and movement.(Dwijayanti, 2015)

The subject matter in reproductive health gymnastics given is in accordance with the initial goal of making reproductive health gymnastics videos, namely to maintain reproductive health in terms of increasing hemoglobin levels and reducing 


\section{STRADA Jurnal Ilmiah Kesehatan}

DOI: $10.30994 /$ sjik.v9i2.448

ISSN: 2252-3847 (print); 2614-350X (online)

Vol.9 No.2 November 2020 Page.1196-1206

dysmenorrhea. Based on the opinion of gymnastics experts, exercise movements are light movements that are safe for the reproductive organs with a duration that can increase oxygen levels in the body. The goals to be achieved in doing regular exercise affect the frequency and duration of exercise. Based on Fitria's research in 2019 on reproductive health gymnastics to improve physical fitness and hemoglobin levels, reproductive health gymnastics is recommended to be carried out 3 times a week with a duration of \pm 20 minutes each time because it has the goal of improving body fitness. The expected objectives can be achieved and can increase the affective consideration aspects that can motivate adolescents to increase physical / psychomotor activity. However, in one week it is better to be spaced per day to give the body time to rest (Putri, Syahrastani, \& Tohidin, 2018)

Reproductive health gymnastics videos, when viewed from the robustness aspect, show that the media has consistent product resistance, because videos cannot change without the editing process. In addition, the reproductive health gymnastics video media can be utilized well by adolescents on a large scale.

\section{B. Feasibility Test for Reproductive Health Gymanastics Video Media}

The results of the collection of information concluded that the anemia management program so far was only by providing blood-supplemented tablets, which not all students were obedient to taking, and there had been no special efforts to deal with students who were experiencing dysmenorrhea. Efforts to fulfill nutrition in order to overcome anemia and dysmenorrhea can be supported by increasing physical activity, one of which is by doing routine reproductive health gymnastics.(Fitria et al., 2018) The benefits provided by reproductive health gymnastics are not in accordance with the socialization process carried out, so there needs to be a socialization media that is easier for adolescent girls to access.

In the millennial era like now, the majority of all forms of information are packaged in digital form. Information in digital form can be entered into electronic devices, namely smartphones, which are telephone devices. The smartphone generation is the impact of rapid technological developments. In the March 2012-2013 period, smartphone ownership in Indonesia doubled, from $12 \%$ to $24 \%$ of the total population in Indonesia. Meanwhile, cellular phone users increased by $10 \%$ to reach $84 \%$ of Indonesia's total population in March 2013.(Papastergiou, 2009) The rapid development of smartphones can be a challenge and an opportunity, especially in the world of health. A special opportunity that can be exploited is to create a medium to help reduce adolescent reproductive health problems by developing reproductive health gymnastics videos.

Based on the cone of experience concept, it is explained that we will remember $5 \%$ of what we hear, $10 \%$ of what we read, $20 \%$ of what we hear and read, $30 \%$ of what is exhibited, $50 \%$ of group discussions, $75 \%$ of what we do and $90 \%$ of what we teach.(Shaluhiyah Z. \& N., 2017) Video tutorials are a method of providing information that uses audio and visual aspects to be demonstrated by the target, so that the information will be remembered more by the respondent than if providing information only uses audio or visual aspects.

This is in line with the results of research conducted by Tindaon in 2016 on education through leaflet and video media which explains that video media is more effective in changing knowledge than leaflets, because videos use sound effects and moving images that can display directed steps, so that make it easy to receive the 


\section{STRADA Jurnal Ilmiah Kesehatan}

DOI: $10.30994 /$ sjik.v9i2.448

ISSN: 2252-3847 (print); 2614-350X (online)

Vol.9 No.2 November 2020 Page.1196-1206

information submitted.(Tindaon, 2018) Research conducted by Shah in 2016 on the effectiveness of educational videos in increasing knowledge of oral health in the hospital environment also explains that educational media in the form of videos can significantly increase knowledge.(Shah, Mathur, Kathuria, \& Gupta, 2016)

Based on the results of the expert validity test, the reproductive health gymnastics video media is feasible and relevant as a media for socializing reproductive health gymnastics. The expert validation process is important in developing models that are useful in health promotion activities, ${ }^{65}$ good media will support the learning process for the practice of implementing reproductive health gymnastics. The assessment of the feasibility of the reproductive health gymnastics video media by adolescents explained that the majority of adolescents considered that the reproductive health gymnastics video media was appropriate to be used as a media for socializing reproductive health gymnastics.

\section{CONCLUSION}

The reproductive health gymnastics video media fulfills 7 aspects of feasibility, namely subject matter, auxiliary information, affective considerations, interface, navigation, pedagogy, and robustness so that the media can be said to be suitable for use.

The reproductive health gymnastics video media based on the analysis of the validity test of 3 experts, namely material experts, health promotion, and practitioners and the test on 30 adolescents shows that the reproductive health gymnastics video is suitable to be used as a media for socializing reproductive health gymnastics for adolescent girls. Video is a medium for providing information that uses audio and visual aspects so that the information provided is easy to receive and more focused.

\section{REFERENSI}

Article, R. (2016). Iron deficiency anaemia. https://doi.org/10.1016/j.hgmx.2015.06.008

Aziza, N. (2015). Kejadian Dismenorhoe Pada Mahasiswi Dengan Anemia. Window of Health Jurnal Kesehatan, XI(2), 170-175.

Budiharjo, T., Qomariah, N., Kesehatan, J. A., Semarang, P. K., \& Asuh, A. (2018). Deteksi Anemia dan Pendampingan pada Anak Asuh, 14(1), 36-40.

Cholifah, A. A. H. (2015). Hubungan Anemia, Status Gizi, Olahraga dan Pengetahuan dengan Kejadian Dismenore pada Remaja Putri, 1(1).

Denis, R. S., \& Conway, J. L. (2018). Iron deficiency and aerobic endurance performance in a female club runner Carence en fer et performance aérobie chez une coureuse de. Science \&amp; Sports. https://doi.org/10.1016/j.scispo.2018.04.012

Dwijayanti, K. (2015). Pengaruh Intensitas Latihan Senam Aerobik High Impact, Low Impact, dan Mix Impact Terhadap Physical Effeciency Index Ditinjau dari Denyut Nadi Istirahat, 1(2), 19-36.

Fatmawati, M., Riyanti, E., \& Widjanarko, B. (2016). Perilaku Remaja Puteri dalam Mengatasi Dismenore (Studi Kasus pada Siswi SMK Negeri 11 Semarang ), 4.

Fitria, S., Pujiastuti, R. S. E., \& Mulyantoro, D. K. (2018). Implementasi Senam Kesehatan Reproduksi terhadap Kadar Hemoglobin dan Kebugaran Jasmani Remaja Putri. Poltekkes Kemenkes Semarang.

Ismarozi, D., Utami, S., \& Novayelinda, R. (2015). Efektifitas Senam Dismenore terhadap Penanganan Nyeri Haid Primer pada Remaja, 2(1).

Kementerian Kesehatan RI. (2018). Riset Kesehatan Dasar Indonesia.

Listiana, A. (2016). Analisis faktor-faktor yang berhubungan dengan kejadian anemia gizi 


\section{STRADA Jurnal Ilmiah Kesehatan}

DOI: $10.30994 /$ sjik.v9i2.448

ISSN: 2252-3847 (print); 2614-350X (online)

Vol.9 No.2 November 2020 Page.1196-1206

besi pada remaja putri di smkn 1 terbanggi besar lampung tengah, 7(3), 455-469.

Papastergiou, M. (2009). Computers \& Education Digital Game-Based Learning in high school Computer Science education : Impact on educational effectiveness and student motivation. Computers \& Education, 52(1), 1-12.

https://doi.org/10.1016/j.compedu.2008.06.004

Prawiroharjo, S. (2011). Ilmu Kebidanan. Jakarta: Yayasan Bina Pustaka.

Proverawati, A. (2009). Menarche Menstruasi Pertama Penuh Makna. Yogyakarta: Nuha Medika.

Putri, E. P., Syahrastani, \& Tohidin, D. (2018). Pengaruh Senam Aerobik Mix Impact Terhadap Penurunan Kadar Lemak Tubuh. Jurnal Sains Olahraga Dan Pendidikan Jasmani, 71-82.

Ramandhasari, F. A., \& Legowo, D. M. (2014). Motivasi Wanita Mengikuti Senam Aerobik, 2(1), 1-5.

Saputro, B. (2017). Manajemen Penelitian Pengembangan ( Research \& Development) bagi Penyusun Tesis dan Disertasi. Yogyakarta: Aswaja Presindo.

Shah, N., Mathur, V. P., Kathuria, V., \& Gupta, T. (2016). Effectiveness of An Educational Video in Improving Oral Health Knowledge In A Hospital Setting. Indian Journal of Dentistry, 7(2).

Shaluhiyah Z., \& N., P. P. (2017). Effective Media For Genital Organ Health Education Junior High School Student, 8, 192-199.

Tahun, M. (2016). Pengaruh Senam Anti Nyeri Haid Terhadap Pengurangan Dismenore di SMA Negeri 5 Kota Magelang, 5(11).

Tindaon, R. L. (2018). Pengaruh Komunikasi, Informasi, dan Edukasi (Kie) Melalui Media Leaflet dan Video Terhadap Pengetahuan dan Sikap Remaja Tentang Paparan Pornografi Di SMP Negeri 1 Sidamanik Kec. Sidamanik Kab. Simalungun Tahun 2016, 3(1), 44-64.

Vandermeulen, H., \& Sholzberg, M. (2018). : Iron deficiency and anemia in patients with inherited bleeding disorders. Transfusion and Apheresis Science, 0502(18). https://doi.org/10.1016/j.transci.2018.10.015

Widayanti, D. S., Mudayanti, S., \& Susmini. (2017). Pengaruh Aktivitas Olahraga Senam Body Language terhadap Penurunan Intensitas Nyeri Dismenore Primer pada Remaja Putri Sman 2 Teluk Keramat Kabupaten Sambas (Kalimantan Barat), 2, 156-164.

World Health Organization. (2011). The Global Prevalence of Anemia in 2011. 